The postulated factors were shown to be significant predictors of the level of autonomy a subsidiary was likely to enjoy for marketing decisions.

COLUMBIA UNIVERSITY, 1977

Permission to reprint abstracts by S. Abahti, S. J. Mascarenhas, and J. Picard has been granted by University Microfilms International, 300 N. Zeeb Road, Ann Arbor, Michigan, 48106.

\title{
NEW BOOKS AND OTHER PUBLICATIONS RECEIVED
}

Burgoyne, John, and Stuart, Rogers, ed., Management and Development: Context and Strategies. A Personnel Review Monograph. Westmead, Eng.: 1978.

Eiteman, David K., and Stonehill, Arthur I. Multinational Business Finance. Reading, Mass.: 1978.

Johnston, Douglas M., ed. Regionalization of the Law of the Sea. Proceedings of the Eleventh Annual Conference, Honolulu, 1977. Cambridge, Mass.: Ballinger Publishing Company, 1978.

Mason, R. Hal. International Business in the Pacific Basin. Lexington: D. C. Heath, 1978.

Ross, Arthur. Politics and Economics in an Interdependent World. Collected Papers. Philadelphia: University of Pennsylvania Press, 1978.

Utrecht, Ernst. Transnational Corporations in South East Asia and the Pacific. vol. 1. With contributions by Kate Short. Transnational Corporations Research Project. Sydney: University of Sydney, 1978.

Winchester, Mark B., ed. The International Essays for Business Decision Makers, vol. 3. Dallas: Amacom, 1978. 